\title{
ANINTANSI BISNIS\& MANAEENEN \\ ANALISIS PELAYANAN DAN HARGA TERHADAP KEPUASAN PELANGGAN PERUSAHAAN DAERAH AIR MINUM
}

\author{
Erik Irawan Suganda \\ Program Studi Manajemen Universitas Pakuan, Bogor \\ Jl. Pakuan, RT.02/RW.06, Tegallega, Kecamatan Bogor Tengah, Kota Bogor, Jawa Barat 16129 \\ E-Mail: eriksuganda@gmail.com
}

Doi: https://doi.org/10.35606/jabm.v28i1.804

\section{Akuntansi Bisnis dan Manajemen (ABM),}

Vol. 28

No. 01

Halaman 1-10,

Bulan April, Tahun 2021

ISSN 0854-4190

E-ISSN 2685-3965

\section{Informasi Artikel \\ Tanggal Masuk: \\ 01 Desember 2020 \\ Tanggal Revisi:}

26 Februari 2021

Tanggal Diterima:

06 Maret 2021

\section{Abstract}

The purpose of this study was to determine the service and price and its impact on customer satisfaction of the Regional Water Supply Company (PDAM), Parung Panjang Branch, Bogor Regency. The study population was customers at the agency as many as 12,524 people with a total sample of 100 people calculated using the Slovin formula. The collection of variable data was examined using a questionnaire with a rating scale. Data analysis techniques using inferential descriptive statistics. The results showed: (1) There was a positive and significant effect on service to customer satisfaction, (2) There was a positive and significant effect on price on customer satisfaction, and (3) There was a positive and significant effect on service and price together on customer satisfaction.

Keywords: service; price; customer satisfaction

\section{Abstrak}

Tujuan penelitian ini adalah untuk mengetahui pelayanan dan harga serta dampaknya terhadap kepuasan pelanggan Perusahaan Daerah Air Minum (PDAM) Cabang Parung Panjang Kabupaten Bogor. Populasi penelitian adalah pelanggan pada instansi tersebut sejumlah 12.524 orang dengan jumlah sampel sebanyak 100 orang yang dihitung menggunakan rumus Slovin. Pengumpulan data variabel yang diteliti menggunakan kuesioner dengan skala rating. Teknik analisis data menggunakan statistik deskriptif inferensial. Hasil penelitian menunjukkan: (1) Terdapat pengaruh positif dan signifikan pelayanan terhadap kepuasan pelanggan, (2) Terdapat pengaruh positif dan signifikan harga terhadap kepuasan pelanggan, dan (3) Terdapat pengaruh positif dan signifikan pelayanan dan harga secara bersama-sama terhadap kepuasan pelanggan

Kata Kunci: pelayanan; harga; kepuasan pelanggan. 


\section{PENDAHULUAN}

Jumlah penduduk Indonesia yang semakin meningkat khususnya Kabupaten Bogor, menyebabkan peningkatan yang searah akan kebutuhan sarana dan prasarana publik, khususnya layanan penyediaan sarana air bersih. Masalah air bersih ini merupakan tugas serta tanggung jawab BUMD yaitu Perusahaan Daerah Air Minum (PDAM) Tirta Kahuripan Kabupaten Bogor yang salah satu cabangnya berada di Parung Panjang. Sebagai salah satu hal yang penting dan perlu mendapat prioritas dalam perencanaan daerah, PDAM perlu memperhatikan tingkat pelayanan serta harga yang ditawarkan karena dapat mempengaruhi tingkat kepuasan pelanggan (Haryoko et al., 2020).

Kotler \& Amstrong (2014) mendefinisikan Kepuasan Konsumen adalah Performa dari suatu produk yang dikonsumsi dan hasilnya sesuai dengan harapan dari seorang konsumen. Konsumen akan merasa tidak terpenuhi kepuasaannya ketika performa dari suatu produk tidak sesuai dengan harapannya. Sebaliknya, ketika performa dari suatu produk sesuai dengan yang diharapkan, maka kepuasan konsumen akan tercapai. Konsumen akan merasa lebih terpenuhi kepuasannya ketika performa produk melebihi ekspektasi yang diharapkan. Jika kepuasan Konsumen terpenuhi dengan baik maka konsumen akan meyampaikannya kepada calon konsumen baru. Sehingga, keuntungan akan dirasakan oleh konsumen dan konsumen.

Di sisi lain, Sholeh (2019) menyatakan bahwa kualitas layanan (service quality) merupakan penyebab yang berpengaruh terhadap tingkat kesetiaan konsumen pada produk maupun jasa. Ketika kualitas suatu produk rendah, konsumen akan menjadi tidak setia. Perusahaan harus meningkatkan kualitas pelayanannya agar kesetiaan pelanggan juga ikut meningkat. Kesimpulannya, ketika kita memperhatikan kualitas suatu produk, maka kita akan lebih mudah memperoleh kesetiaan dan kepuasan konsumen. Pernyataan ini diperkuat dengan hasil penelitian Triantoro et al., (2015), yang menyatakan bahwa kualitas pelayanan berpengaruh positif dan signifikan terhadap kepuasan pelanggan.

Sebagai salah satu bukti nyata bahwa PDAM telah melakukan peningkatan pada kualitas pelayanannya, PDAM Kabupaten Bogor selalu meraih peningkatan skor dalam penilaian kinerja pada setiap tahunnya. Pada tahun 2016 skornya 3,95 poin, kemudian naik menjadi 4,1 poin pada tahun 2017, tahun 2018 naik lagi menjadi 4,2 poin, terakhir tahun 2019 skor menjadi 4,24 poin (Setiawan, 2020). PDAM Kabupaten Bogor dalam praktiknya tidak hanya mengalami peningkatan pada skor dalam penilaian kerja saja, melainkan juga mendapat keluhan dari masyarakat mengenai buruknya pelayanan yang diberikan. Salah satu keluhan yang disampaikan adalah PDAM tidak melaksanakan proses instalasi atau pemasangan saluran air, bahkan tidak memberitahukan progress atas permintaan instalasi yang dikirimkan. Masyarakat tidak hanya mengeluh mengenai layanan PDAM Kabupaten Bogor yang tidak sesuai harapan, tetapi masyarakat juga menyampaikan keluhan lain yaitu melonjaknya harga tagihan air yang tidak wajar. Padahal salah satu indikator nilai yang digunakan konsumen dalam merasakan kegunaan dari barang atau jasa adalah harga. Ketidaksesuaian antara harga dengan manfaat produk akan menyebabkan 
menurunnya tingkat kepuasan konsumen. Semakin tingginya nilai yang konsumen rasakan maka kepuasan konsumen akan semakin tercipta (Gofur, 2019).

Untuk meminimalisir keluhan masyarakat terhadap layanan sangat perlu dilakukan oleh PDAM Kabupaten Bogor, karena ketika masyarakat atau pelanggan merasa puas dengan pelayanan yang berikan, maka minat pelanggan untuk menggunakan jasanya akan kembali muncul (Haryoko et al., 2020). Kepuasan masyarakat menjadi aspek penting yang perlu diperhatikan oleh PDAM Tirta Kahuripan Cabang Parung Panjang. Hal-hal seperti kualitas pelayanan dan harga menjadi dua aspek yang dapat digunakan oleh konsumen dalam menikmati pelayanan yang berikan oleh perusahaan. Pelayanan yang diberikan perusahaan dalam waktu yang panjang dapat meraih kepuasan konsumen dengan baik.

Beberapa hasil penelitian terdahulu terkait dengan kepuasan konsumen dilakukan antara lain oleh Maulana (2016). Ia menyebutkan bahwa kualitas pelayanan berpengaruh sebesar 73\% dalam mempengaruhi kepuasan konsumen dan sebesar 27\% dipengaruhi oleh faktor lain, begitu juga yang disampaikan oleh Haryoko et al., (2020). Hasil dari penelitiannya menunjukkan hasil yang sama yaitu kualitas pelayanan mempengaruhi kepuasan konsumen secara signifikan dan positif. Hasil kedua penelitian tersebut pun diperkuat dengan hasil penelitian Gofur (2019) yang menyimpulkan bahwa terdapat pengaruh yang positif serta signifikan antara kualitas pelayanan terhadap kepuasan konsumen. Sehingga dari uraian diatas didapat hipotesis sebagai berikut:

$\mathrm{H}_{1}$ : Kualitas Pelayanan secara parsial berpengaruh positif dan signifikan terhadap Kepuasan Pelanggan.

Penelitian tentang kepuasan konsumen yang dipengaruhi oleh harga disampaikan oleh Aswad et al., (2018) menyatakan bahwa harga adalah berbagai macam biaya yang dikeluarkan oleh konsumen untuk mendapatkan sejumlah barang dan pelayanan dari produk yang ia peroleh. Ketidaksesuaian antara harga dengan manfaat produk akan menyebabkan menurunnya tingkat kepuasan konsumen. Semakin tingginya nilai yang konsumen rasakan maka kepuasan konsumen akan semakin tercipta (Gofur, 2019). Pada penelitian Aswad et al., (2018) dan Gofur (2019) keduanya memiliki persamaan hasil yaitu terdapat pengaruh positif serta signifikan antara harga dengan kepuasan konsumen. Pernyataan tersebut juga sesuai dengan hasil penelitian Safrizal (2015) menyatakan bahwa harga secara parsial berpengaruh positif dan signifikan terhadap kepuasan konsumen. Sehingga berdasarkan uraian diatas, dapat ditarik hipotesis sebagai berikut:

H2: Harga secara parsial berpengaruh positif dan signifikan terhadap Kepuasan Pelanggan.

Maulana (2016) melalui penelitiannya menyimpulkan bahwa kualitas Pelayanan dan Harga secara simultan memengaruh sebesar 83,1\% terhadap Kepuasan Pelanggan, pernyataan tersebut juga sesuai dengan hasil penelitian Safrizal (2015) yang 
menyatakan bahwa hipotesis kedua yaitu terdapat pengaruh positif dan signifikan antara harga dan kualitas pelayanan secara simultan terhadap kepuasan konsumen, hal ini diketahui dari uji F, F hitung > F tabel $(94,240>3,938)$. Sehingga dapat ditarik hipotesis sebagai:

$\mathrm{H}_{3}$ : Kualitas Pelayanan dan Harga secara simultan berpengaruh positif dan signifikan terhadap Kepuasan Pelanggan.

Berdasarkan penjelasan sebelumnya, maka kerangka berfikir selengkapnya tampak pada Gambar 1 berikut ini.

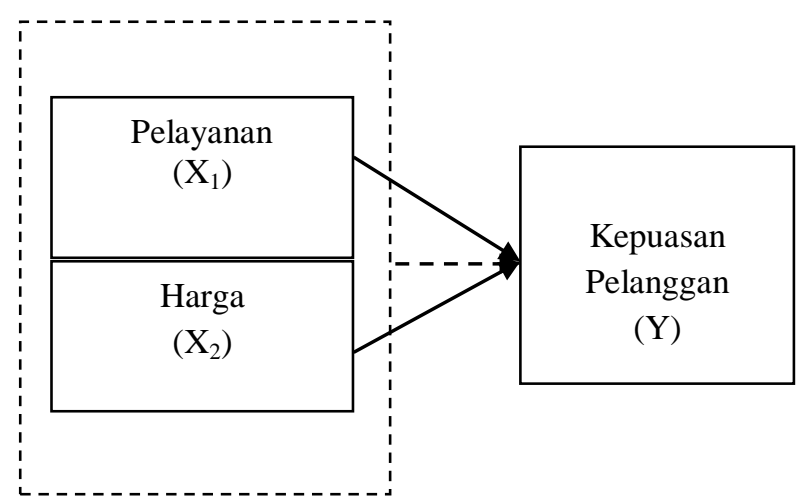

Gambar 1. Kerangka Berfikir

\section{METODE PENELITIAN}

Pada penelitian ini penulis menggunakan metode penelitian yang disebut dengan metode survey serta pendekatan yang digunakan adalah pendekatan korelasi, dapat diartikan bahwa metode ini digunakan penulis guna memperoleh informasi mengenai pengaruh antara variabel-variabel tidak sejenis yang diteliti dalam suatu populasi. Metode yang disebutkan diatas digunakan penulis untuk memperoleh data dari sejumlah konsumen pada rentan waktu bersamaan. Penelitian ini menganalisis pengaruh dua variabel, yaitu variable independen dan dependen. Variabel indenpenden adalah variabel bebas yang dapat mempengaruhi atau menyebabkan perubahan pada variabel terikat (variabel dependen). Variabel indenpenden atau variabel bebas yang diteliti pada penelitian ini antara lain kualitas pelayanan $\left(\mathrm{X}_{1}\right)$ dan harga produk $\left(\mathrm{X}_{2}\right)$. Variabel dependen atau Variabel terikat merupakan variabel yang dipengaruhi atau berubah karena adanya pengaruh dari variabel independen (variabel bebas) dan yang menjadi variabel terikat dalam penelitian ini adalah kepuasan pelanggan (Y).

Populasi dalam penelitian ini sebanyak 12.524 orang dan jumlah sampel yang diteliti adalah sebanyak 100 orang. Jumlah tersebut didapat dengan cara menghitung populasi menggunakan rumus Slovin. Teknik mengumpulkan data variabel yang diteliti menggunakan kuesioner dengan skala rating. Tanggapan Responden atas Variabel kualitas pelayanan diukur dengan menggunakan indikator sebagai berikut: Bukti Fisik, Kehandalan, Daya Tanggap, Jaminan, dan Empathy. Harga produk diukur menggunakan indikator sebagai berikut: Produk, Tingkat Persaingan dan Tingkat 
Promosi. Terakhir, indikator yang digunakan untuk mengukur Kepuasan pelanggan antara lain Kualitas Produk, Harga, Kualitas Pelayanan, Faktor Emosional dan Kemudahan (Irawan, 2009).

Teknik analisis yang digunakan adalah analisis statistik deskriptif dan analisis statistik inferensial. Analisis statistik deskriptif dapat diartikan dengan teknik mencatat serta meringkas suatu data penelitian guna menjelaskan hal-hal penting pada sekelompok data, sedangkan analisis statistik inferensial dapat diartikan cara mengambil kesimpulan atas data yang telah dianalisis menggunakan teknik analisis deskriptif (data telah dicatat secara ringkas) berkaitan dengan pengambilan kesimpulan dari data yang telah dicatat dan diringkas.

\section{HASIL DAN PEMBAHASAN}

\section{Pengaruh Pelayanan terhadap Kepuasan Pelanggan}

Uji hubungan antara pelayanan dengan kepuasan pelanggan dengan uji korelasi sederhana Product Moment (Pearson) maka diperoleh nilai koefisien korelasi sebesar $r_{\mathrm{y} .1}=0,794$. Nilai koefisien korelasi $r_{\mathrm{y} .1}=0,794$ adalah positif $(+)$ dan nilai korelasi $\neq 0$. Hasil ini menunjukkan bahwa terdapat hubungan positif antara pelayanan dengan kepuasan pelanggan. Derajat kekuatan hubungan yang terjadi antara pelayanan dengan kepuasan pelanggan termasuk kategori "kuat" dikarenakan bahwa nilai $\mathrm{r}_{\mathrm{y} .1}=$ 0,794 berada diantara nilai 0,600 - 0,799 (kuat).

Hubungan yang terjadi dikatakan signifikan apabila nilai $t_{\text {hitung }}>$ nilai $t_{\text {tabel }}$. Signifikan artinya bahwa hubungan yang terjadi adalah nyata dalam arti bahwa keberadaan pelayanan berhubungan secara nyata dengan kepuasan pelanggan. Hasil uji signifikansi menunjukkan bahwa nilai $t_{\text {hitung }}=12,944$ dan nilai $t_{\text {tabel }}=1,99$ pada tingkat Sig = 0,05 dan N -2 atau $100-2=98$. Hasil ini menunjukkan bahwa bahwa nilai $t_{\text {hitung }}=12,944>$ nilai $t_{\text {tabel }}=1,99$, artinya bahwa hubungan antara pelayanan dengan kepuasan pelanggan adalah signifikan. Dengan demikian dapat disimpulkan terdapat hubungan positif yang signifikan antara pelayanan dengan kepuasan pelanggan.

Setelah diketahui bahwa hubungan yang terjadi antara pelayanan dengan kepuasan pelanggan adalah positif dan signifikan. Koefisian determinasi pada penelitian ini digunakan untuk menguji seberapa besar pengaruh antara pelayanan terhadap kepuasan konsumen. Hasil analisis koefisien determinasi adalah $r^{2}=\left(r_{\mathrm{y} .1}\right)^{2}=(0,794)^{2} \mathrm{x}$ $100 \%=63,1 \%$. Hasil ini menunjukkan bahwa besarnya pengaruh pelayanan adalah sebesar 63,1\% terhadap kepuasan pelanggan.

Dari hasil penelitian yang telah dilakukan oleh peneliti sebelumnya, kesimpulan yang dapat ditarik adalah terdapat pengaruh positif dan signifikan antara pelayanan dengan kepuasan pelanggan. Artinya, semakin meningkatnya pelayanan dari suatu produk maka semakin meningkat pula kepuasan pelanggan dan sebaliknya. Produsen diharapkan dapat memenuhi keinginan konsumen secara konsisten, karena hal tersebut merupakan penilaian dari konsumen atas pelayanan barang atau jasa yang di konsumsi. Kesetiaan (loyalitas), rekomendasi dari konsumen ke konsumen serta memperbaiki citra perusahaan merupakan dapat positif yang dapat perusahaan rasakan ketika konsumen merasa puas atas pelayanan yang diberikan. Perusahaan 
harus menjadikan pelayanan yang maksimal sebagai fokus utama karena dapat menyebabkan banyak dampak positif bagi perusahaan. Hal tersebut sesuai dengan hasil penelitian (Gofur, 2019) yang memperoleh kesimpulan bahwa variabel kualitas pelayanan memiliki pengaruh yang signifikan dan positif terhadap variabel kepuasan pelanggan.

\section{Pengaruh Harga terhadap Kepuasan Pelanggan}

Uji hubungan antara harga dengan kepuasan pelanggan dengan uji korelasi sederhana Product Moment (Pearson) maka diperoleh nilai koefisien korelasi sebesar $r_{y .2}=0,639$. Nilai koefisien korelasi $r_{y .2}=0,639$ adalah + dan nilai korelasi $\neq 0$ Hasil ini menunjukkan bahwa terdapat hubungan positif antara harga dengan kepuasan pelanggan. Derajat kekuatan hubungan yang terjadi antara harga dengan kepuasan pelanggan termasuk kategori "kuat" dikarenakan bahwa nilai $\mathrm{r}_{\mathrm{y} .2}=0,639$ berada diantara nilai 0,60 - 0,799 (kuat).

Uji $\mathrm{t}$ adalah menguji apakah hubungan yang terjadi antara harga dengan kepuasan pelanggan dengan nilai koefisien korelasi sebesar $r_{y .2}=0,639$ signinikan atau tidak. Hubungan yang terjadi dikatakan signinikan apabila nilai $t_{\text {hitung }}>$ nilai $t_{\text {tabel }}$. Signifikan artinya bahwa hubungan yang terjadi adalah nyata dalam arti bahwa keberadaan harga berhubungan secara nyata dengan kepuasan pelanggan. Hasil uji signifikansi menunjukkan bahwa nilai $t_{\text {hitung }}=8,223$ dan nilai $t_{\text {tabel }}=1,99$ pada tingkat Sig $=0,05$ dan $\mathrm{N}-2$ atau $100-2=98$. Hasil ini menunjukkan bahwa bahwa nilai $t_{\text {hitung }}$ $=8,223>$ nilai $t_{\text {tabel }}=1,99$, artinya bahwa hubungan antara harga dengan kepuasan pelanggan adalah signifikan. Dengan demikian dapat disimpulkan terdapat hubungan positif yang signifikan antara harga dengan kepuasan pelanggan.

Setelah diketahui bahwa hubungan yang terjadi antara harga dengan kepuasan pelanggan adalah positif dan signifikan. Selanjutnya untuk mengetahui seberapa besar pengaruh harga terhadap kepuasan pelanggan maka dilakukan analisis dengan menggunakan koefisien determiansi. Hasil analisis koefisien determinasi adalah $\mathrm{r}^{2}=$ $\left(r_{y .2}\right)^{2}=(0,639)^{2} \times 100 \%=40,8 \%$. Hasil ini menunjukkan bahwa besarnya pengaruh harga adalah sebesar 40,8\% terhadap kepuasan pelanggan. Dari hasil penelitian yang telah dikemukakan sebelumnya, dapat disimpulkan bahwa harga berpengaruh positif dan signifikan terhadap kepuasan pelanggan. Semakin meningkat harga, maka semakin meningkat kepuasan pelanggan dan sebaliknya.

Setelah melakukan pembelian, konsumen akan mulai memberikan penilaian harga, hal tersebut konsumen lihat dari kesesuaian antara pengorbanan yang telah ia keluarkan dengan feedback yang ia terima. Selain itu, penilaian harga juga akan menimbulkan persepsi konsumen atas barang atau jasa yang dibeli. Ketika konsumen merasa puas atas pembelian suatu barang atau jasa makan akan menimbulkan persepsi positif. Sebaliknya, ketika konsumen mereka tidak puas atas pembelian yang dilakukan, maka persepsi yang timbul adalah persepsi negatif. Pernyataan diatas linear dengan hasil penelitian dari Hosang et al., (2016) yang menyatakan bahwa secara parsial terdapat pengaruh positif dan signifikan antara harga dengan kepuasan konsumen. 


\section{Pengaruh Pelayanan dan Harga Secara Bersama-sama (Simultan) terhadap Kepuasan Pelanggan}

Uji hubungan secara simultan atau bersama-sama antara pelayanan dan harga dengan kepuasan pelanggan menggunakan uji korelasi berganda diperoleh nilai koefisien korelasi sebesar $\mathrm{R}=0,802$. Nilai koefisien korelasi $\mathrm{R}=0,802$ adalah + dan nilai korelasi $\neq 0$. Hasil ini menunjukkan bahwa antara pelayanan dengan kepuasan pelanggan memiliki pengaruh yang positif. Derajat kekuatan hubungan yang terjadi antara budaya organisasi dan komitmen organisasional secara bersama-sama dengan kepuasan pelanggan termasuk kategori "sangat kuat" dikarenakan bahwa nilai $\mathrm{R}=$ 0,802 berada diantara nilai 0,80 - 1,000 (sangat kuat).

Selanjutnya adalah dengan menggunakan nilai koefisien korelasi sebesar $R=0,802$, apakah terdapat hubungan yang signifikan antara pelayanan dan harga dengan kepuasan pelanggan. Hubungan yang terjadi dikatakan signinikan apabila nilai $\mathrm{Ft}_{\text {hitung }}$ $>$ nilai $\mathrm{F}_{\text {tabel. }}$ Signifikan artinya bahwa hubungan yang terjadi adalah nyata dalam arti bahwa secara simultan atau bersama-sama keberadaan pelayanan dan harga memiliki hubunga yang nyata dengan kepuasan pelanggan. Hasil uji signifikansi menunjukkan bahwa nilai $F_{\text {hitung }}=87,315$ dan nilai $F_{\text {tabel }}=3,1$ pada tingkat $a=0,05$. Hasil ini menunjukkan bahwa bahwa nilai $\mathrm{F}_{\text {hitung }}=87,315>$ nilai $\mathrm{F}_{\text {tabel }}=3,1$, artinya bahwa hubungan antara pelayanan dan harga secara bersama-sama dengan kepuasan pelanggan adalah signifikan. Dengan demikian ditarik kesimpulan bahwa pelayanan dan harga secara simultan atau bersama-sama memiliki pengaruh positif dan signifikan terhadap kepuasan pelanggan.

Setelah diketahui bahwa secara simultan atau bersama-sama pelayanan dan harga memiliki hubungan yang positif dan signifikan, selanjutnya dilakukan pengujian untuk mengetahui seberapa besar pelayanan dan harga secara simultan berpengaruh terhadap kepuasan pelanggan, maka dilakukan analisis menggunakan koefisien determiansi. Hasil analisis koefisien determinasi adalah $R^{2}=(R)^{2}=(0,802)^{2} \times 100 \%=$ $64,3 \%$. Hasil ini menunjukkan bahwa pengaruh pelayanan dan harga secara bersamasama adalah sebesar $64,3 \%$ terhadap kepuasan pelanggan.

Untuk mengetahui persamaan regresi berganda didapatkan persamaan regresi berganda: $\hat{Y}=17,279+0,655 X_{1}+0,457 X_{2}$. Hasil persamaan regresi berganda ini dapat dijelaskan sebagai berikut :

1) Nilai konstanta sebesar 17,279 , artinya apabila pelayanan dan harga secara bersama-sama tidak ada maka nilai kepuasan pelanggan $(Y)$ sebesar 17,279.

2) Nilai koefisien pelayanan $\left(X_{1}\right)$ sebesar 0,655 , artinya bahwa apabila ada kenaikan atau tambahan (karena tanda + ) satu satuan pelayanan $\left(X_{1}\right)$ maka akan terjadi peningkatan kepuasan pelanggan $(\mathrm{Y})$ sebesar 0,655 satu satuan.

3) Nilai koefisien harga $\left(X_{2}\right)$ sebesar 0,457 , artinya bahwa akan terjadi peningkatan kepuasan pelanggan (Y) sebesar 0,457 apabila ada kenaikan atau tambahan (karena tanda + ) satu satuan harga $\left(X_{2}\right)$.

4) Hasil hubungan fungsional menunjukkan bahwa secara simultan pelayanan dan harga secara dengan kepuasan pelanggan yaitu $\hat{Y}=17,279+0,655 X_{1}+0,457 X_{2}$ menjelaskan bahwa pelayanan dan harga secara bersama-sama dapat digunakan untuk memprediksi kepuasan pelanggan. 
Berdasarkan hasil uraian sebelumnya, penulis menarik kesimpulan bahwa secara bersama-sama (simultan) terdapat pengaruh positif dan signifikan antara pelayanan konsumen dan harga terhadap kepuasan konsumen. Dua hal penting yang dapat berpengaruh terhadap kepuasan pelanggan antara lain pelayanan dan harga. Pelayanan dan kepuasan pelanggan berbanding lurus, yang berarti ketika pelayanan yang diberikan maksimal maka akan menghasilkan tingkat kepuasan konsumen yang tinggi. Pelayanan konsumen dapat dikategorikan berkualitas dan memuaskan ketika konsumen merasa bahwa nilai yang mereka terima sesuai harapan atau bahkan melebihi harapan tersebut. Selain pelayanan, harga juga menjadi faktor yang memengaruhi kepuasan konsumen. Menurunnya tingkat kepuasan konsumen disebabkan oleh harga suatu produk tidak sesuai dengan manfaat yang dirasakan, tingkat kepuasan konsumen juga dapat meningkat ketika harga yang ditetapkan oleh perusahaan berbanding lurus dengan manfaat yang diterima oleh konsumen. Uraian diatas relevan dengan hasil penelitian (Sholeh, 2019), penelitian tersebut menunjukan bahwa secara simultan kualitas pelayanan dan harga berpengaruh positif dan signifikan terhadap kepuasan pelanggan.

\section{KESIMPULAN DAN SARAN}

Berdasarkan uraian sebelumnya, penulis menyimpulkan bahwa pelayanan dan harga berpengaruh signifikan dan positif terhadap kepuasan pelanggan. Terdapat $63,1 \%$ pengaruh pelayanan terhadap kepuasan pelanggan. Kesetiaan (loyalitas), rekomendasi dari konsumen ke konsumen serta memperbaiki citra perusahaan merupakan dapat positif yang dapat perusahaan rasakan ketika konsumen merasa puas atas pelayanan yang diberikan. Secara parsial, 40,8\% harga berpengaruh terhadap kepuasan konsumen. Konsumen akan mulai memberikan penilaian harga setelah melakukan pembelian. Penilaian harga sendiri menunjukkan kesesuaian antara pengorbanan yang telah ia keluarkan dengan feedback yang ia terima. Selain itu, penilaian harga juga akan menimbulkan persepsi konsumen atas barang atau jasa yang dibeli. Ketika konsumen merasa puas atas pembelian suatu barang atau jasa makan akan menimbulkan persepsi positif. Sebaliknya, ketika konsumen mereka tidak puas atas pembelian yang dilakukan, maka persepsi yang timbul adalah persepsi negatif.

Secara simultan, pelayanan dan harga memiliki pengaruh sebesar 64,3\% terhadap kepuasan peanggan. Pelayanan dan kepuasan pelanggan berbanding lurus, yang berarti ketika pelayanan yang diberikan maksimal maka akan menghasilkan tingkat kepuasan konsumen yang tinggi. Pelayanan konsumen dapat dikategorikan berkualitas dan memuaskan ketika konsumen merasa bahwa nilai yang mereka terima sesuai harapan atau bahkan melebihi harapan tersebut. Menurunnya tingkat kepuasan konsumen disebabkan oleh harga suatu produk tidak sesuai dengan manfaat yang dirasakan, tingkat kepuasan konsumen juga dapat meningkat ketika harga yang ditetapkan oleh perusahaan berbanding lurus dengan manfaat yang diterima oleh konsumen. Hal ini berarti bahwa kepuasan pelanggan pada PDAM Cabang Parung Panjang, Kabupaten Bogor dipengaruhi masing-masing pelayanan, harga, dan pelayanan dan harga secara bersamaan. Pelayanan dan harga yang meningkat (naik) 
akan meningkatkan kepuasan pelanggan, dan sebaliknya jika pelayanan dan harga yang menurun (rendah) maka kepuasan pelanggan juga rendah.

Berdasarkan kesimpulan ini, pelayanan dan harga pada PDAM Cabang Parung Panjang, Kabupaten Bogor perlu terus ditingkatkan karena memberikan kontribusi terhadap peningkatan kepuasan pelanggan. Kemudian diharapkan untuk penelitian selanjutnya membahas mengenai faktor-faktor lain di luar pelayanan dan harga yang berpengaruh terhadap kepuasan pelanggan, misalnya iklim organisasi, budaya organisasi, kepuasan kerja, dan faktor-faktor lainnya.

\section{DAFTAR PUSTAKA}

Aswad, S., Realize, R., \& Wangdra, R. (2018). Pengaruh Harga Dan Kualitas Pelayanan Terhadap Kepuasan Konsumen Pengguna Air Bersih Masyarakat Kampung Air Batam Center. JIM UPB (Jurnal Ilmiah Manajemen Universitas Putera Batam), 6(2), 77. https://doi.org/10.33884/jimupb.v6i2.681

Gofur, A. (2019). Pengaruh Kualitas Pelayanan Dan Harga Terhadap Kepuasan Pelanggan. Jurnal Riset Manajemen Dan Bisnis (JRMB), 4(1), 37-44.

Haryoko, U. B., Delimah Pasaribu, V. L., \& Ardiyansyah, A. (2020). Pengaruh Harga Dan Kualitas Pelayanan Terhadap Kepuasan Konsumen Pada Firman Dekorasi (Wedding Organizer). Point, 2(1). https://doi.org/10.46918/point.v2i1.566

Hosang, N., Tumbel, A., \& Moniharapon, S. (2016). Analisis Pengaruh Kualitas Pelayanan Dan Harga Terhadap Kepuasan Pasien (Studi Kasus Pada Rumah Sakit Siloam Manado). Jurnal Berkala Ilmiah Efisiensi, 16(01), 159-171.

Irawan, H. (2009). 10 Prinsip Kepuasan Pelanggan. Elex Media Komputindo.

Kotler, P., \& Amstrong, G. (2014). Principles of Marketing (15th ed.). Education, Inkc.

Maulana, A. S. (2016). Pengaruh Kualitas Pelayanan Dan Harga Terhadap Kepuasan Pelanggan PT. Toi. Jurnal EKonomu: Journal Of Economic, 7(2), 37-44. https://doi.org/10.36226/jrmb.v4i1.240

Safrizal, S. (2015). Pengaruh Harga dan Kualitas Pelayanan terhadap Kepuasan Konsumen pada Restoran Ayam Penyet Pak Ulis di Kota Langsa. Jurnal Manajemen Dan Keuangan Unsam, 4(1), 196969.

Setiawan, M. F. (2020). BPPSPAM-KemenPUPR: PDAM Kabupaten Bogor BUMD berkinerja sehat. https://www.antaranews.com/berita/1673762/bppspamkemenpupr-pdam-kabupaten-bogor-bumd-berkinerja-sehat

Sholeh, Y. (2019). Analisis Kualitas Pelayanan Perusahaan Daerah Air Minum (Pdam) Tirta Alami Kabupaten Kepahiang. Jurnal Pendidikan Ekonomi, 4(9).

Triantoro, K., Hadi, S. P., Suryoko, S., \& Triantoro, K. (2015). Pengaruh Kualitas Pelayanan dan Harga Terhadap Kepuasan PelangganPengguna Jasa Kereta Api 
Menoreh Kelas Ekonomi Studi Kasus Pada PT . Kereta Api Indonesia DAOP IV Semarang. Journal Of Social And Political Of Science. 